\title{
Changes in mesozooplankton size structure along a trophic gradient in the California Current Ecosystem and implications for small pelagic fish
}

\author{
Ryan R. Rykaczewski ${ }^{1,2, *}$ \\ ${ }^{1}$ Scripps Institution of Oceanography, University of California San Diego, La Jolla, CA 92093, USA \\ ${ }^{2}$ Present address: School of the Earth, Ocean, \& Environment, Department of Biological Sciences, \\ University of South Carolina, Columbia, SC 29208, USA
}

\begin{abstract}
Stocks of sardine and anchovy inhabiting eastern boundary upwelling systems of the world's oceans have exhibited large fluctuations in population size, often with peaks in biomass of one taxon alternating with that of the other over multidecadal periods. One hypothesis offered to explain such variability attributes changes in population growth to distinctions in the optimal size of the fishes' planktonic prey. However, the factors affecting size structure in mesozooplankton assemblages are poorly understood. Here, plankter sizes and concentrations were measured for samples collected across a trophic gradient in the California Current Ecosystem with coincident measures of nutrient concentrations. There was a clear distinction between mesozooplankter sizes in samples from oligotrophic and eutrophic waters, with the relative abundances of large individuals being greater in areas where upwelling conditions enhanced nutrient availability and increased abundances of large phytoplankters. The relative contributions of small zooplankters were greater in oligotrophic waters. In light of the observed variability in the biomasses and size structures of phytoplankton and zooplankton assemblages, the potential growth rates of sardine and anchovy are estimated using previously established models of ingestion, absorption, excretion, and respiration. These bioenergetic models suggest that the potential for anchovy growth is limited to nearshore, eutrophic waters where large zooplankters are abundant. In contrast, growth of sardine is possible under more oligotrophic conditions and is influenced by oceanographic conditions in the offshore region of the ecosystem.
\end{abstract}

KEY WORDS: Sardine $\cdot$ Sardinops sagax $\cdot$ Anchovy $\cdot$ Engraulis spp. $\cdot$ Zooscan · Upwelling · Planktivourous fishes $\cdot$ Clupeiformes

\section{INTRODUCTION}

Sardine Sardinops sagax and anchovy (Engraulis spp.) are ecologically important as consumers of biological production and as prey for mammals, birds, and piscivorous fishes, and they support valuable commercial fisheries. However, the large degree of multidecadal variability in the biomasses of these populations has long stimulated concern among oceanographers and resource managers. Population sizes of the 2 taxa have often alternated in dominance in the world's eastern boundary current upwelling

${ }^{*}$ Corresponding author: ryk@sc.edu

${ }^{\S}$ Advance View was available online July 17, 2018;

subsequently updated July 30, 2018 ecosystems which they inhabit (Schwartzlose et al. 1999), fueling speculation that sardine and anchovy have differing sensitivities to environmental changes (Checkley et al. 2017). One hypothesis explaining the differing responses of each taxon to environmental forcing suggests that the interspecific differences are related to the distinct size classes of zooplankters and phytoplankters on which they feed (Alheit \& Niquen 2004, van der Lingen et al. 2006, Rykaczewski \& Checkley 2008, Ayón et al. 2011).

Concentration and size structure of the zooplankton assemblage are key factors influencing individ-

( ) The author 2019. Open Access under Creative Commons by Attribution Licence. Use, distribution and reproduction are unrestricted. Authors and original publication must be credited. 
ual growth and feeding behavior of mature sardine and anchovy (van der Lingen et al. 2009). Juveniles and adults of both taxa are omnivorous planktivores capable of 2 modes of prey capture (Leong \& O'Connell 1969, James 1988): non-selective filter feeding and particulate feeding (active biting of individual prey items). Leong \& O'Connell (1969) and James \& Findlay (1989) examined the factors influencing feeding mode and rates of prey ingestion for anchovy from 2 upwelling systems, finding that northern anchovy E. mordax from the California Current and Cape anchovy E. capensis from the Benguela Current employ particulate feeding when large zooplankters compose a significant portion of the zooplankton assemblage. Filter feeding is used only as the concentration of large prey items declines. Closer investigation of the prey consumption and bioenergetic expenditure of anchovy demonstrated that filter feeding is an inefficient mode of prey capture, and exclusive filtering is unlikely to provide the level of nutrition necessary to meet daily requirements (O'Connell 1972, James et al. 1989). Observations of prey consumption in the field substantiate these laboratory findings; Koslow (1981) observed that anchovy actively select the largest plankters available in the environment.

Examinations of $S$. sagax feeding behavior and prey consumption show that individual growth is also subject to limitations related to prey size and concentration. However, the fine-mesh branchial sieve of sardine is capable of capturing much finer planktonic prey than E. capensis and E. mordax (van der Lingen 1994). In comparison to anchovy, sardine filter feed over a greater portion of the plankton size spectrum and are capable of retaining prey items smaller than $20 \mu \mathrm{m}$. Selection of individual prey items by particulate feeding is energetically inefficient in comparison to filter feeding. When presented with similar prey assemblages in the natural environment, items consumed by sardine are distinctly smaller than those consumed by anchovy (Louw et al. 1998). An understanding of how the biomass size spectra of phytoplankton and zooplankton assemblages vary with respect to environmental conditions may elucidate the factors influencing production and growth of sardine and anchovy populations.

The relationship between the size structure of marine phytoplankton assemblages and resource availability is well documented. Typically, oligotrophic assemblages are dominated by small cells, and the proportion of large cells increases with increasing availability of nutrients (Chisholm 1992). Allometric relationships governing rates of nutrient uptake, cell respiration, and the response of zooplankton grazing pressure are often cited as the underlying ecological processes responsible for the relationship between assemblage size spectra and nutrient concentrations. Small cells have a large surface area to volume ratio, conferring a competitive advantage over large cells in regard to nutrient uptake rate (Morel et al. 1991). In eutrophic environments where nutrient constraints are reduced, populations of large cells flourish while smaller phytoplankters are restricted by size-dependent microzooplankton grazing (Riegman et al. 1993). An alternate hypothesis suggests that upward vertical velocity in the water column, independent of nutrient supply, may result in an increased contribution of large cells to the phytoplankton assemblage by decreasing the net sinking rate of large cells from the euphotic zone. The sinking rates of small phytoplankters, which experience relatively low-Reynolds-number environments where viscous forces dominate, are not influenced by differences in vertical motion (Rodríguez et al. 2001). In the California Current Ecosystem (CCE), the relative contribution of small phytoplankters decreases as total chlorophyll a (chl a) increases (Mullin 1998).

In contrast, factors influencing the size structure of the mesozooplankton prey relevant for sardine and anchovy remain unclear. Many previous investigations of zooplankton size structure in the marine environment have emphasized changes over the complete size spectrum (ranging from bacteria to metazoa) and commonly attribute the shape of the biomass spectrum to allometric scaling of physiological rates, predator-prey interactions, and the efficiency of energy transfers among trophic levels within the ecosystem (Zhou \& Huntley 1997). These studies provide insight into the characteristics of the ecosystem as a whole but provide little understanding of the structure and function of the particular biological communities of direct importance to planktivorous fish. However, continued development of zooplankton imaging methodologies and their application to process zooplankton collected during regular oceanographic surveys has fostered insight into the relationships among hydrographic processes, biogeochemical conditions, and mesozooplankton size spectra and the potential implications for fish recruitment (Grosjean et al. 2004, Irigoien et al. 2009, Manriquez et al. 2009, Medellin-Mora et al. 2016).

In addition to controlling the transfer of nutrients and organic matter to higher predators, the size structure of mesozooplankton assemblages is an important factor influencing carbon export and nutrient regeneration. Vertical particle flux attributed to 
the fecal pellets of meso- and macrozooplankters contributes to the export of organic carbon, while the high mass-specific metabolic rates of small zooplankters promote rapid nutrient regeneration (Ikeda et al. 2001). Understanding of mesozooplankton size structure is important in partitioning production between microbial recycling and export to higher trophic levels (Legendre \& Michaud 1998) and is a key component of ecosystem and biogeochemical models (Moloney \& Field 1991, Buitenhuis et al. 2006).

How might we expect zooplankter sizes to vary across a trophic gradient? There is abundant evidence to suggest that large zooplankters are inefficient at using small phytoplankters as prey, and there is an optimal predator:prey ratio which maximizes the transfer of energy and organic matter from phytoplankton to zooplankton in pelagic ecosystems (Frost 1974, Moloney \& Field 1991, Hansen et al. 1994). Hence, a decrease in zooplankter sizes with decreases in phytoplankter sizes and nutrient supply is expected. Here, I posed the question: How does the size spectrum of the mesozooplankton vary with changes in the sizes of their phytoplanktonic prey in the marine environment? I address this question by examining biomass spectra of phytoplankton and mesozooplankton assemblages in relation to the nutrient content and physical conditions for samples collected across a trophic gradient in the CCE. The implications of changes in plankter sizes for the nutritional budgets of sardine and northern anchovy are considered in the context of previously established bioenergetic models.

\section{MATERIALS AND METHODS}

\subsection{Process cruises}

Ecosystem structure was investigated in the southern region of the CCE during 2 research cruises (May 2005 and June 2006) as part of the CCE Long-Term Ecological Research Program. Water masses of differing characteristics were tracked with a subsurface drogue over several days while intensively sampling chemical, physi$\mathrm{cal}_{\text {, and biological properties at a diel }}$ frequency (Landry et al. 2009). This
4-5 d sampling 'cycle' was successfully repeated 8 times during the 2 cruises in regions ranging from the eutrophic coastal zone to the oligotrophic region offshore. Cycle locations were selected along a transect line approximately perpendicular to the coast, and these locations are plotted against a background of chl a concentrations as estimated by the Moderate Resolution Imaging Spectrometer (Fig. 1). One of these experimental cycles was conducted in shallow water ranging from 68 to $200 \mathrm{~m}$, and data from this cycle were excluded from further analysis as the collection methods applied were not uniform with those at other locations.

Zooplankton were collected with a $0.71 \mathrm{~m}$ diameter paired bongo net with $202 \mu \mathrm{m}$ Nitex mesh towed obliquely from $210 \mathrm{~m}$ depth between 21:00 and 04:00 h (local time). I focused on nighttime samples so that diel changes in zooplankton abundance would not confound possible differences in size structure. The volume of water filtered was estimated

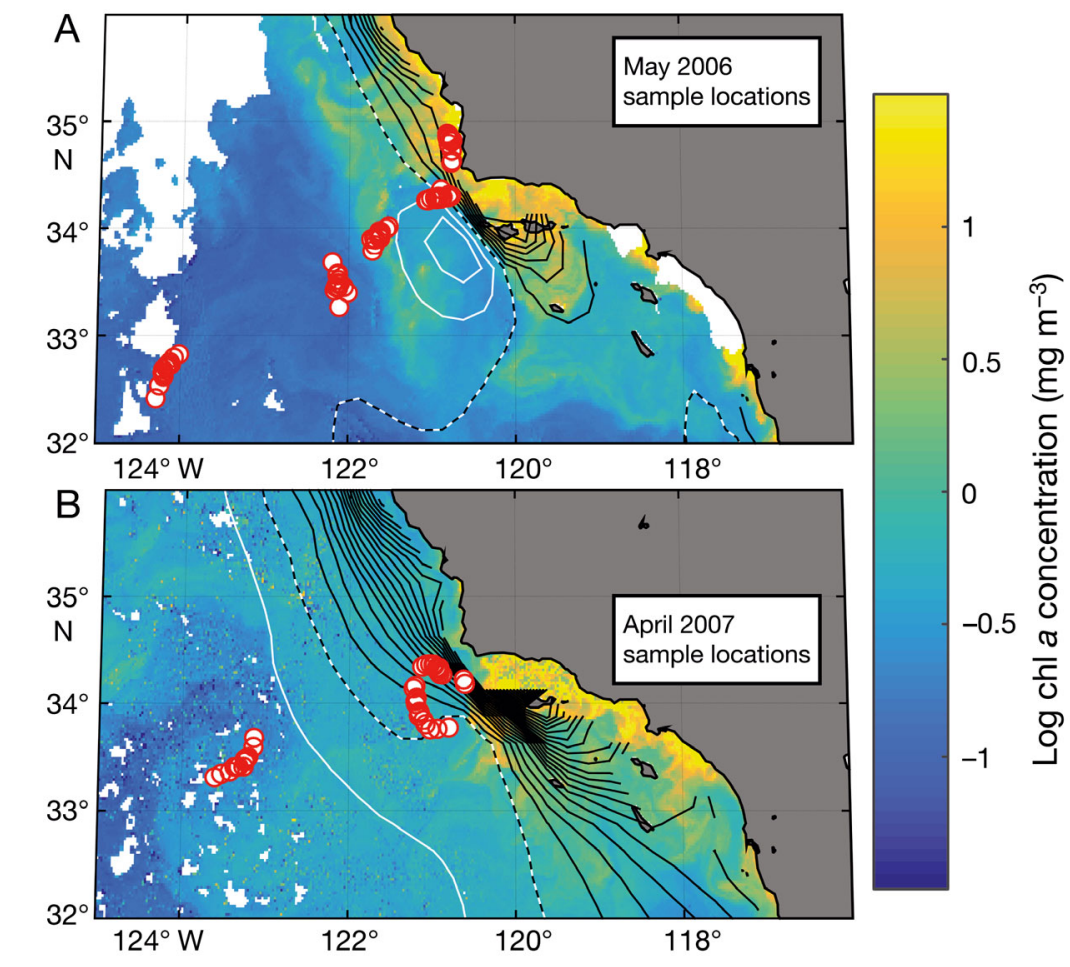

Fig. 1. Locations of experimental cycles in reference to remotely sensed chlorophyll a ( $\mathrm{chl}$ a) concentrations and estimates of curl-driven upwelling. Sampling locations ranged from the eutrophic region nearshore to the oligotrophic region offshore. Contour lines denote curl-driven upwelling rate in $0.1 \mathrm{~m} \mathrm{~d}^{-1}$ increments. The 0 contour is dashed, negative contours are in white, and positive contours are in black. Each red circle indicates the location of a mesozooplankton sample examined microscopically in the laboratory. These images of conditions on (A) 23 May 2006 and (B) 18 April 2007 were two of only a few images in which cloud cover did not obscure the study region. Curl-driven upwelling rates are averages over the $7 \mathrm{~d}$ prior to the dates above 
using calibrated flowmeters in the mouth of each net. Zooplankton from one of the paired nets were preserved in sodium-borate buffered formaldehyde for microscopic analysis. A portion of the zooplankton from the other paired net was split into size fractions using nested Nitex filters of decreasing mesh size, and zooplankton concentrations in these 5 size categories were measured by dry-weight analysis (Rykaczewski \& Checkley 2008).

Water column properties were measured using a CTD/rosette cast between 01:00 and 02:40 h each morning. Water samples for macronutrient content were collected from at least 8 depths above the thermocline and stored at $-20^{\circ} \mathrm{C}$, and concentrations of nitrate were determined calorimetrically by an automated analyzer at the Marine Science Institute (Santa Barbara, California). The nutricline location was determined by locating the largest gradient in nitrate concentration with depth. Water samples for analysis of phytoplankton size spectra were collected from the mixed layer and filtered onto 6 filters of differing pore size $(256 \mathrm{ml}$ each onto a $0.7 \mu \mathrm{m}$ glass fiber filter and nested 1, 3, 8, and $20 \mu \mathrm{m}$ polycarbonate filters) and repeated in triplicate fashion. Chlorophyll was extracted from each filter overnight while immersed in $7 \mathrm{ml}$ of $90 \%$ acetone at $-2^{\circ} \mathrm{C}$ and analyzed for chl a concentration using a Turner Designs fluorometer (Holm-Hansen et al. 1965).

Wind stress and upwelling rate resulting from windstress curl (i.e. Ekman pumping) at each sampling location were calculated using a wind product generated from a blending of wind stress measured by a satellite scatterometer and a mesoscale atmospheric model (Chao et al. 2003). Use of the blended model al- lowed estimation of wind speed and upwelling rate at locations inshore of $50 \mathrm{~km}$ where satellite scatterometer measurements are unreliable. Curl-driven upwelling rate was estimated at the base of the mixed layer (Smith 1968) and averaged over $7 \mathrm{~d}$ prior to zooplankton sampling. Wind-stress magnitude was similarly averaged over the $7 \mathrm{~d}$ prior to sampling.

\subsection{Zooplankton sample preparation and enumeration}

A fraction of each zooplankton sample was optically imaged using the Zooscan system (Grosjean et al. 2004). Prior to scanning, the preserved samples were split into 2 coarse size fractions using a $1 \mathrm{~mm}$ sieve. Two sets of Zooscan images were created for each zooplankton sample: 1 set for each of the size fractions. Separating the sample into these coarse fractions was intended to allow identification of relatively scarce, large individuals that would not have been detected had the sample been considered en masse. Between 0.5 and $10 \%$ of each sample volume (at least 3000 individual particles from each net tow) was imaged using Zooscan.

Automated measurements of particle size, shape, and gray-scale density were performed using Zooprocesss analysis software (Benfield et al. 2007). Each particle was described by 22 measurements and classified into 1 of 9 broad taxonomic categories (Table 1) using the random forest technique (Breiman 2001). Taxonomic categories were chosen to resolve the dominant members of the mesozooplankton, defined here as the zooplankton that were retained by the

Table 1. Taxonomic categories and length to dry weight conversions applied in Zooscan analysis. TL: total length; PL: prosome length; TrL: trunk length; ShL: shell length

\begin{tabular}{|lll|}
\hline Taxonomic group & Length to dry weight conversion & Reference \\
\hline Copepods & & \\
Calanoid copepods & $\log _{10} \mathrm{DW}=3.358 \times \log _{10}(\mathrm{PL})-9.159$ & Kobari et al. (2004) \\
Eucalanid copepods & $\log _{10} \mathrm{DW}=3.091 \times \log _{10}(\mathrm{PL} / 1000)-0.0026$ & Hopcroft et al. (2002) \\
Oithona spp. copepods & $\log _{10} \mathrm{DW}=3.16 \times \log _{10}(\mathrm{TL})-8.18$ & Hopcroft et al. (1998) \\
Poecilostomatoid copepods & $\ln \mathrm{DW}=2.90 \times \ln (\mathrm{TL})-16.82$ & Satapoomin (1999) \\
Harpacticoid copepods & $\ln \mathrm{DW}=1.59 \times \ln (\mathrm{TL})-10.23$ & Satapoomin (1999) \\
Euphausiids & $\log _{10} \mathrm{DW}=0.456+2.8 \times \log _{10}(\mathrm{TL} / 1000)$ & Lindley et al. (1999) \\
Chaetognaths & $\log _{10} \mathrm{DW}=3.24 \times \log _{10}(\mathrm{TL} / 1000)-0.975$ & Uye (1982) \\
Appendicularians & $\mathrm{DW}=\left(38.8 \times(\mathrm{TrL} / 1000)^{2.574}\right)^{1.12}$ & Lavaniegos \& Ohman $(2007)$ \\
Ostracods & $\mathrm{DW}=17.072 \times(\mathrm{TL} / 1000)^{2.545}$ & Lavaniegos \& Ohman $(2007)$ \\
Polychaetes & $\mathrm{DW}=40.322 \times \mathrm{TL} / 1000$ & Lavaniegos \& Ohman $(2007)$ \\
Pteropods & $\mathrm{DW}=1.615 \times \mathrm{e}^{0.088}$ ShL/1000 & Lavaniegos \& Ohman $(2007)$ \\
Siphonophores & $\mathrm{DW}=20.47 \times(\mathrm{TL})^{0.834}$ & Lavaniegos \& Ohman $(2007)$ \\
Detritus and other minor & Excluded from analysis & \\
zooplankton taxa & & \\
\hline
\end{tabular}


$202 \mu \mathrm{m}$ mesh bongo sampling. The copepod assemblage composed the majority of the biomass in each sample and was further classified into 5 categories representing distinctive body shapes. A training set of manually identified zooplankters was compiled in collaboration with other researchers investigating mesozooplankton assemblages in the CCE (namely M. D. Ohman and A. Cawood). Zooplankters were sorted among these taxonomic categories with a success rate $>80 \%$. Items identified as detritus were excluded from further analysis. Here, the term 'Zooscan' will be used to refer to the joint method Zooscan scanning and Zooprocess analysis.

Zooscan measurements of zooplankter lengths were converted to manually measured lengths using taxonomically specific, linear relationships developed for a subset of preserved individuals collected in the CCE (Gorsky et al. 2010). Body lengths were converted to individual dry mass using relationships from the literature (Table 1). Estimation of zooplankter sizes using Zooscan offers some advantage over in situ measures (e.g. optical plankton counters) which have difficulty distinguishing between living zooplankters and detrital aggregates (GonzalezQuiros \& Checkley 2006, Checkley et al. 2008). Use of Zooscan permits a broad level of taxonomic resolution, and aggregates of phytoplankton in the samples may be intentionally excluded from analysis of zooplankton, as was done here. Furthermore, the rapid scanning and machine identification techniques associated with Zooscan processing allows examination of a greater number of individuals than would be permitted by manual microscopic identification.

\subsection{Estimation of normalized-biomass spectral slopes}

Zooplankters were grouped into logarithmically increasing size categories (equally spaced on a log scale base $2^{0.333}$ ), and the summed dry weight in each category was divided by the change in weight across the category to create a normalized-biomass spectrum for each sample (Platt \& Denman 1978). A linear least-squares line was fit to the spectrum to describe the change in normalized biomass with individual body weight for each sample:

$$
\log \left(\frac{B_{w}}{\Delta w}\right)=m[\log (w)]+b
$$

where $B_{W}$ is the sample biomass in each dry-weight category $w, \Delta w$ is the biomass interval for each fraction, and $m$ and $b$ are the slope and $y$-intercept of the linear, best-fit line. The dry weight $(w)$ of each zooplankton size category was taken as the geometric mean of the weight values bounding the category. Individuals with an estimated dry weight $>80 \mu \mathrm{g}$ (equivalent to a copepod of $2 \mathrm{~mm}$ prosome length) were excluded from the calculation of spectra slope. Exclusion of these largest individuals was warranted for 3 reasons: (1) The grazing efficiencies of both sardine and anchovy are dependent on the variability of prey sizes < $2000 \mu \mathrm{m}$ (van der Lingen 1994); changes in the size distribution of larger individuals is not thought to influence ingestion rate. (2) Individual abundances of zooplankters decrease with increasing sizes, while net avoidance increases. The calculation of biomass spectral slope is increasingly susceptible to biases as larger, rarely sampled individuals are considered. Although attempts were made to avoid undersampling of large individuals by fractionating the sample prior to Zooscan analysis, artifacts remained obvious after recombination of the small and large size fractions. (3) This division excludes individuals with generation times > 30 d (Gillooly 2000), allowing examination of assemblage structure influenced by the local environment separate from those consisting of individuals with life histories influenced by a variety of conditions over a longer period of time.

Normalized-biomass spectra of zooplankton typically displayed local minima for the smallest biomass classes (Fig. 2). These minima are sampling artifacts related to incomplete retention of small organisms. Organisms with body widths 1.33 times the mesh size of the net are captured with about 95\% efficiency (Harris et al. 2000). If we assume a width:length ratio of 0.25 for copepods, then individuals with total length $<1075 \mu \mathrm{m}$ will be captured with $<95 \%$ efficiency by the $200 \mu \mathrm{m}$ mesh net used here. I excluded all organisms $<1100 \mu \mathrm{m}$ total length (corresponding to calanoid copepods $<8 \mu \mathrm{g}$ ind. ${ }^{-1}$ ), and this truncation of the biomass spectra avoided biases due to incomplete retention of small zooplankters. To examine the capability of the Zooscan analysis to approximate zooplankton biomass and spectral slope, these estimates were compared with those measured by sequential mesh fractionation and oven drying (Rykaczewski \& Checkley 2008). The latter dataset was converted to account for fractionation based on individual linear dimension rather than on dry weight, as used here.

Normalized-biomass spectra were also used to describe size structure in phytoplankton assemblages. Conversion of size-fractionated chlorophyll measurements to phytoplankton dry weight requires 


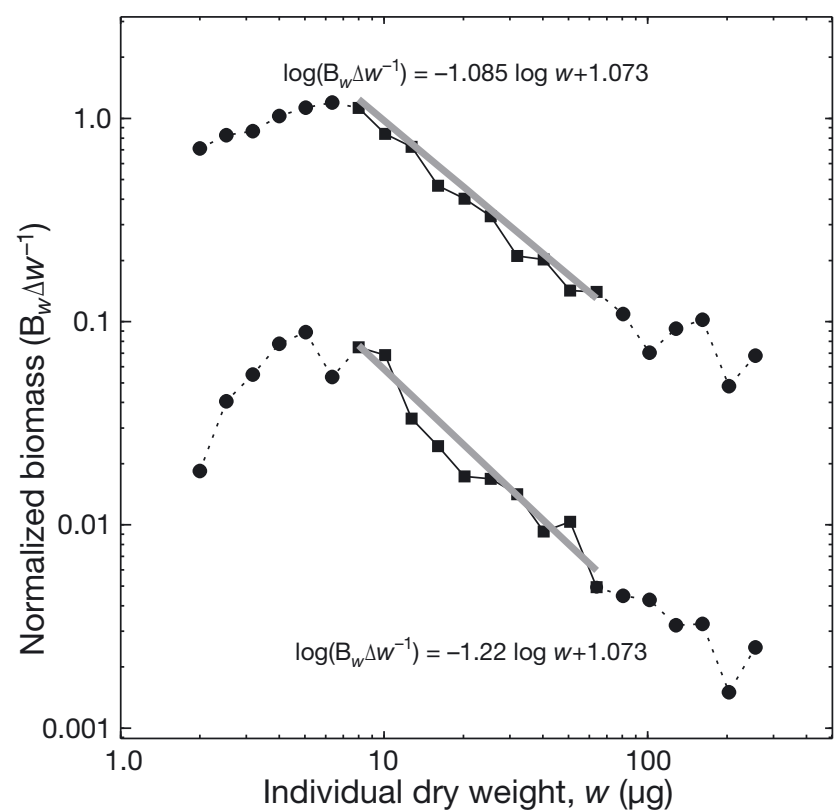

Fig. 2. Typical normalized-biomass spectra. The vertical and horizontal axes are log scale. The upper example is the spectrum from a sample collected in 2007 in the nearshore region (38 km from the coast), and the lower example is from a sample collected in 2006 from the offshore region $(385 \mathrm{~km}$ from the coast). The straight lines and equations estimate the normalized-biomass spectra over the size ranging from 8 to $80 \mu \mathrm{g}$ (see 'Materials and methods'). Dotted lines and circles indicate data excluded from the calculation of biomass spectral slopes. Individuals less than about $8 \mu \mathrm{g}$ dry weight were incompletely retained by the $202 \mu \mathrm{m}$ mesh net. Individuals larger than $80 \mu \mathrm{g}$ dry weight were absent in some samples

use of 3 ratios, the carbon:chl $a$, carbon:wet weight, and volume:wet weight ratios. Carbon:chl a ratios were measured in the mixed layer during each sampling cycle using epifluorescence microscopy. This ratio ranged from 34 to 151 by weight (Taylor et al. 2015). Phytoplankter carbon content was assumed equal to $37 \%$ of dry weight (Strickland 1960). The equivalent spherical diameters of the phytoplankton size classes were taken as the geometric mean of the pore sizes of the 2 filters defining the size categories, and a diameter of $80 \mu \mathrm{m}$ was taken as the upper boundary of the largest size class. To convert from size categories based on individual diameters to categories based on individual mass, I applied the volume:wet weight conversion of Mullin et al. (1966). A linear least-squares estimate of the normalizedbiomass spectrum was calculated for each phytoplankton sample in a manner identical to that applied to the zooplankton.

To better describe the empirical relationships among nitrate concentrations, phytoplankton biomasses, mesozooplankton biomasses, and the spec- tral slopes of the phytoplankton and mesozooplankton assemblages sampled during the cruises, the pairwise correlations (nonparametric Spearman rank correlations) between these properties were estimated. To explore the changes in the taxonomic composition and zooplankter sizes within the mesozooplankton samples, Wilcoxon rank-sum tests were used to estimate whether samples from eutrophic (nitrate concentrations above the nutricline exceeded $1.0 \mu \mathrm{M} \mathrm{l}^{-1}$ ) or oligotrophic (nitrate concentrations above the nutricline were less than $1.0 \mu \mathrm{M} \mathrm{l}^{-1}$ ) stations differed in the distribution of individual zooplankter sizes or in the contributions of taxa to the overall mesozooplankton biomass. Additionally, Spearman rank correlations were applied to test for relationships between these mesozooplankton characteristics (i.e. individual zooplankter sizes within each taxonomic group or in the contribution of each taxon to overall biomass) and the spectral slope of the mesozooplankton assemblage.

\subsection{Bioenergetic modeling of sardine and anchovy growth}

Alheit \& Niquen (2004), van der Lingen et al. (2006), and Rykaczewski \& Checkley (2008) hypothesized that the major difference in the response of sardine and anchovy to changing environmental conditions is related to their use of different sizes of prey and the efficiency at which they capture and retain organic matter over different portions of the plankton size spectrum. Laboratory examinations of feeding behavior, respiration, ingestion, and excretion support this hypothesis. To examine the plausibility of this hypothesis, I used the equations describing the carbon and nitrogen budgets developed by James \& Findlay (1989) and van der Lingen (1999) to estimate specific growth rates of sardine and anchovy of the Benguela Current Ecosystem given the plankter sizes and concentrations sampled across the CCE. These models are convenient because they estimate fish growth rates given plankter sizes and concentrations. However, cursory examination of these previously established bioenergetic models suggest that the estimated growth rates at high concentrations and large sizes of plankters are unrealistic. Gross growth efficiencies exceed 0.7 for models of the carbon budgets of both taxa and exceed 0.4 and 0.2 for the nitrogen budget models of anchovy and sardine, respectively. Actual gross growth efficiencies for juvenile or adult fishes rarely exceed 0.25 (Brett \& Groves 1979, Peck et al. 2013). Given these 
biases, it is important to stress that the results from these models may approximate the spatial pattern of maximum potential growth rates; the values of estimated growth under high abundances and large sizes of zooplankters are expected to overestimate actual growth rates.

The linear approximations of mesozooplankton biomass size spectra were extended to estimate the prey available at individual sizes ranging from 200 to $4000 \mu \mathrm{m}$ total length for input into the bioenergetic growth equations. For phytoplankton, the range of size classes required as model input was similar to that sampled directly, and no extrapolation was necessary. Persistent and dense aggregations of plankters likely influence feeding behavior and growth rates of fish. The phytoplankton and zooplankton concentrations used in this exercise represent spatial averages measured by oblique net tows over a towing distance of about $1 \mathrm{~km}$, and the effects of vertical and horizontal variability at scales less than a kilometer were not considered here.

Estimates of mesozooplankton assemblage sizes and biomasses combined with the basic bioenergetic equations derived empirically by James et al. (1989) and van der Lingen (1999) allow approximation of the ingestion and growth of individual sardine and anchovy. Here, I used these equations developed for sardine and anchovy of the Benguela Current Ecosystem (Sardinops sagax and Engraulis capensis, respectively) to estimate mass-standardized specific growth rates based on rates of ingestion, assimilation, excretion, and respiration for sardine and anchovy of the CCE (S. sagax and E. mordax). In these models, ingestion and respiration rates change with swimming speed and feeding mode (i.e. filter feeding or particulate feeding), and both of these behavioral changes are functions of prey size and concentration. Metabolic rates were scaled to adjust for differences between the mixed-layer temperatures observed in the CCE during zooplankton sampling and laboratory temperatures at which the bioenergetic budgets were developed using literature values of $\mathrm{Q}_{10}$ for sardine and anchovy genera (van der Lingen 1995).

The equations provided by James et al. (1989) and van der Lingen (1999) are based on single prey sizes, and I modified these equations slightly to account for the variety of prey sizes available. Clearance rate of anchovy, $F_{\mathrm{A}}$, is related to the concentrations of prey in each of $n$ size classes (modified from 'Equation 5' of James et al. 1989):

$$
F_{\mathrm{A}}=\sum_{n}^{i=1} 17.7 \cdot \mathrm{e}^{\left(-\mathrm{e}^{2.19-1.89\left(x_{i} / 1000\right)}\right)}
$$

in $1 \mathrm{fish}^{-1} \min ^{-1}$ where $x_{i}$ is the length (in $\mu \mathrm{m}$ ) of a prey item in size class $i$. When particulate feeding, clearance rates for prey sizes $<710 \mu \mathrm{m}$ were set at 0 . When filter feeding, clearance rates for particles $>710 \mu \mathrm{m}$ were given a value equal to the clearance rate at $710 \mu \mathrm{m}$. James et al. (1989) observed that swimming speed in anchovy was related to prey size-individuals swam faster when presented with larger prey items, likely a response to the increased escape capabilities of larger individuals. The prey size governing swimming speed in 'Equation 20' of James et al. (1989) was taken as the prey size equivalent to the $90^{\text {th }}$ biomass percentile. Other equations representing the bioenergetics of anchovy were unmodified.

The fifth-order polynomial describing the clearance rate of sardine $\left(F_{\mathrm{S}}\right)$ as presented by van der Lingen (1999) is inappropriate for prey sizes $>2.7 \mathrm{~mm}$ total length, and I chose to modify 'Equation 5' of van der Lingen (1999), fitting a more appropriate equation to the same data:

$$
F_{\mathrm{S}}=\sum_{n}^{i=1} \frac{9.96 \cdot \mathrm{e}^{0.00843\left(x_{i}-800\right)}}{30.8+0.323 \cdot \mathrm{e}^{0.00843\left(x_{i}-800\right)}}+\frac{9.03 \cdot \mathrm{e}^{0.0198\left(x_{i}-15\right)}}{12.03+0.75 \cdot \mathrm{e}^{0.0198\left(x_{i}-15\right)}}
$$

in $1 \mathrm{fish}^{-1} \mathrm{~min}^{-1}$. Clearance rates during different feeding modes were adjusted in a manner similar to that for anchovy. When particulate feeding, clearance rates for prey sizes $<1230 \mu \mathrm{m}$ were set at 0 . When filter feeding, clearance rates for particles $>1230 \mu \mathrm{m}$ were given a value equal to the clearance rate at $1230 \mu \mathrm{m}$.

James \& Findlay (1989) and van der Lingen (1994) noted thresholds governing switches in feeding mode based on the length of a limited variety of prey items. Here, I modified this condition so that feeding mode was based on the mean biomass of individual particles in the assemblage. Strict adherence to the mean length of particles proposed by James \& Findlay (1989) and van der Lingen (1994) would consistently result in filter feeding by both taxa, since small phytoplankters and zooplankters are always numerically dominant. A threshold based on biomass spectra is more appropriate. In the model applied here, fish switched from filter feeding to particulate feeding if more than $50 \%$ of the biomass in the zooplankton assemblage was contained in size classes greater than the thresholds identified in the laboratory experiments of James \& Findlay (1989) and van der Lingen (1994).

The single remaining free parameter in the budget equations presented by James et al. (1989) and van der Lingen (1999) is the amount of time 
available for filter feeding or particulate feeding per day. As the objective of this exercise is to explore the maximum habitat available given the observed prey sizes, I held the maximal time available for particulate feeding at $12 \mathrm{~h} \mathrm{~d}^{-1}$ and the maximal time spent feeding during filter feeding at $24 \mathrm{~h} \mathrm{~d}^{-1}$. Particulate feeding is dependent on visual identification and active selection of prey items. Particulate feeding by anchovy is possible even under low-light conditions (O'Connell 1972) and shows marked periodicity with peaks at dawn and dusk (James 1987). Filter feeding is not light dependent and does not show regular periodicity (van der Lingen 1998, Emmett et al. 2005).

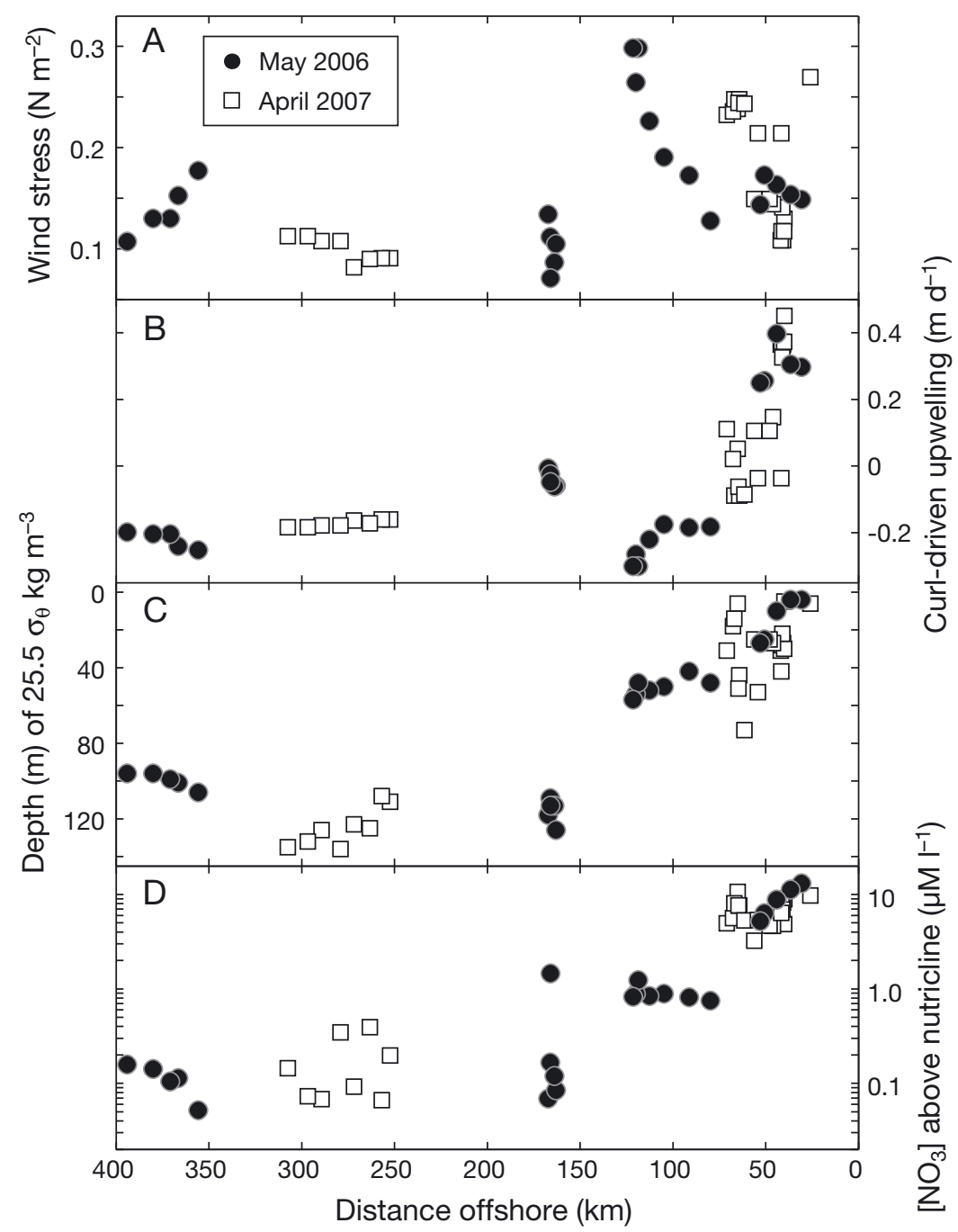

Fig. 3. Physical and chemical conditions observed during sampling of phytoplankton and zooplankton assemblages. (A) Wind-stress magnitudes, (B) curl-driven upwelling rates, (C) depths of the $25.5 \sigma_{\theta}$ isopycnal, and (D) average nitrate concentrations (on a log scale) above the nutricline measured during sampling of phytoplankton assemblage size structure

\section{RESULTS}

Curl-driven upwelling and nitrate content of the mixed layer decreased rapidly with distance offshore during both cruises, and these changes were mirrored by the depth of the $25.5 \mathrm{~kg} \mathrm{~m}^{-3} \sigma_{\theta}$ isopycnal. Winds were predominantly from the northwest (daily mean $=305^{\circ}, \mathrm{SD}=8^{\circ}$ ), and the peak in wind stress magnitude occurred between 25 and $130 \mathrm{~km}$ from shore during sampling for both cruises (Fig. 3A-D). The influence of coastal upwelling in the nearshore region was not distinguished from curl-driven upwelling, wind-driven mixing, or mesoscale dynamical processes, as it is difficult to interpret the location from which the sampled waters originated and the physical processes responsible for the flux of nutrients into the euphotic zone. Given the weekly averaged estimates of wind stress for sampling locations nearest to the coast and assuming that upwelling from Ekman transport away from the coast occurs over a Rossby radius of $10 \mathrm{~km}$, coastal upwelling rates during the cruises ranged from 1.4 to $5.7 \mathrm{~m} \mathrm{~d}^{-1}$, or up to an order of magnitude greater than the largest rates of curl-driven upwelling (Smith 1968). Coastal upwelling, turbulent mixing across the nutricline, and high rates of curl-driven upwelling are probable processes responsible for the increased nutrient content of the nearshore waters. The influence of coastal upwelling decreases with increased distance from the coast as nutrients are utilized by phytoplankton as water masses advect away from the coastal area. In these offshore regions, curl-driven upwelling and turbulent mixing likely contribute a greater portion of nutrient input to the euphotic zone than in regions closer to the coast. Concentrations of phytoplankton declined with distance offshore (Fig. 4A). The slopes of the linear fits to each spectrum became more negative as the pycnocline deepened and the nutrient concentration, wind stress, and curl-driven upwelling rate declined with distance offshore, indicating that the relative contribution of small individuals to 


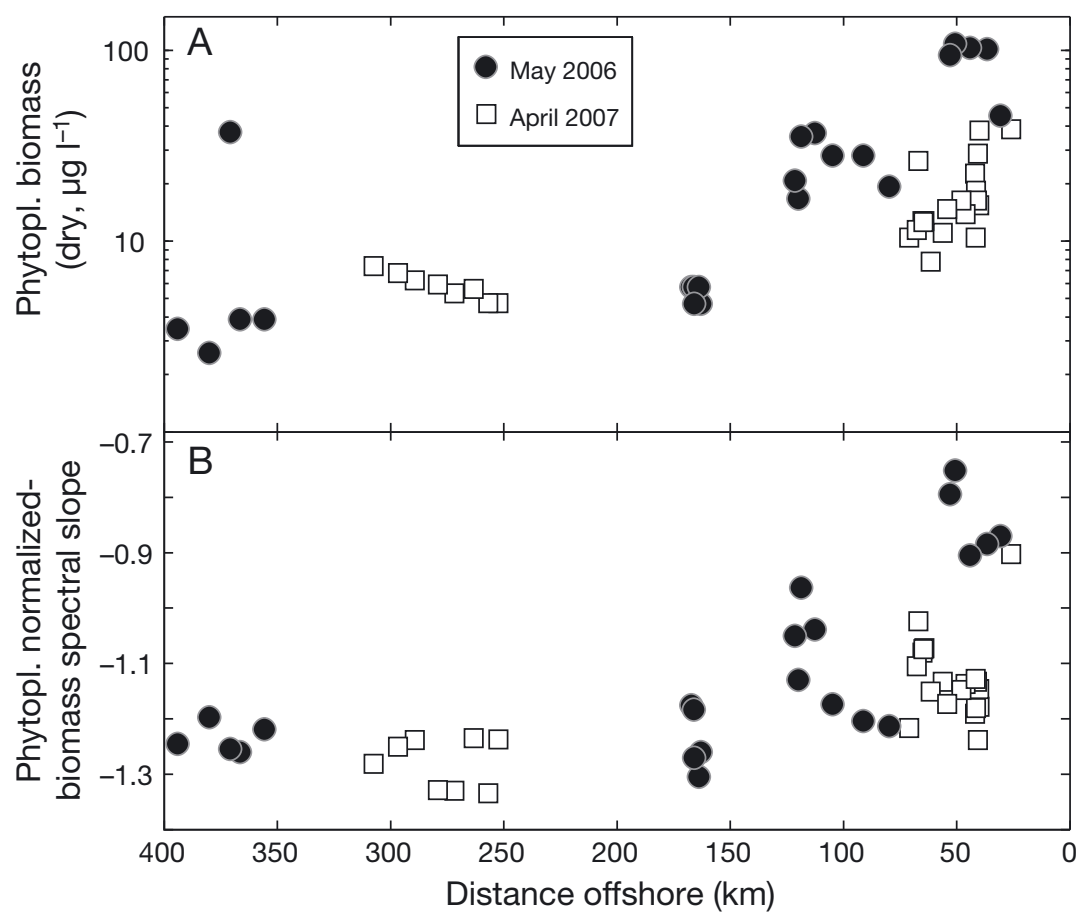

Fig. 4. Measures of biomass and size structure of the phytoplankton assemblage. (A) Phytoplankton concentration was estimated from measures of chlorophyll a ( $\mathrm{chl}$ a) content and carbon:chl a ratio. (B) Slope of the normalized-biomass spectrum for phytoplankton was estimated by chl a fractionation using a series of filters

the phytoplankton assemblage was greater in more oligotrophic environments (Fig. 4B).

The spectral slopes and biomass estimates calculated by the oven-dried method agree well with Zooscan estimates and show similar declines with distance offshore (Fig. 5). However, the slopes calculated by mesh fractionation and oven drying were consistently biased negative, describing a smaller assemblage structure. The small individuals deliberately excluded from Zooscan analysis could not be removed from the wet-sieved samples, and this may be responsible for the bias apparent in the comparison. Similarly, biomasses estimated by mesh fractionation and oven drying were greater than those estimated by Zooscan analysis for samples collected near the coast where large phytoplankters clogged the mesh sieves and were unintentionally included in estimates of zooplankton biomass. For these reasons, only the biomasses and size spectra estimated by Zooscan will be discussed further.

Mean mesozooplankton biomass ranged from $2 \mathrm{mg}$ $\mathrm{m}^{-3}$ offshore to $54 \mathrm{mg} \mathrm{m}^{-3}$ at a nearshore location. Spectral slopes ranged from -1.5 to 0.5 with a mean of -1.0. In light of the high degree of covariation between physical and chemical measurements of the ecosystem (Fig. 3), I chose to represent trophic state by the logarithm of nitrate concentration above the nutricline rather than by each oceanographic data series individually. The relationship between nitrate concentration and the spectral slopes of the phytoplankton and mesozooplankton assemblages was significant (Spearman rank correlation $\mathrm{p}<0.01$; Table 2 ). The relationship between the spectral slopes of the phytoplankton and zooplankton assemblages was also positive, though there was considerable variability in estimates of zooplankton spectral slopes within samples collected at the same location. For each experimental cycle location, the mean and standard deviation of the estimates of spectral slope are plotted with the complete data in Fig. 6. A logarithmic relationship describing the association between nitrate concentration and spectral slopes of the phytoplankton and zooplankton assemblages is displayed in Fig. 7. Slopes of assemblage size spectra are most negative at low concentrations of nitrate and increase to an asymptotic maximum as nitrate levels increase. This relationship is more descriptive of changes in the size structures observed at high and low concentrations of nitrate than of changes in size over a small range of nutrient conditions.

To investigate whether the relationship observed within the mesozooplankton assemblage was the result of shifts in taxonomic composition or of changes in the sizes of individual members of dominant taxonomic groups, I examined the rank correlation between estimated slope and 2 measures of assemblage change: median dry weight of individual zooplankters (Table 3) and percentage composition of major taxa (Table 4). I also examined mean size and taxonomic composition between inshore areas with nitrate concentrations above the nutricline $>1.0$ $\mu \mathrm{M} \mathrm{l}^{-1}$ (i.e. eutrophic areas) and offshore areas with lower nitrate concentrations (i.e. oligotrophic areas). The 5 most abundant taxa identified were copepods, euphausiids, chaetognaths, ostracods, and appendicularians. More specific changes within the copepod group were not examined. Although all major taxa (except ostracods) displayed larger individual size and variability in the eutrophic region nearshore, 


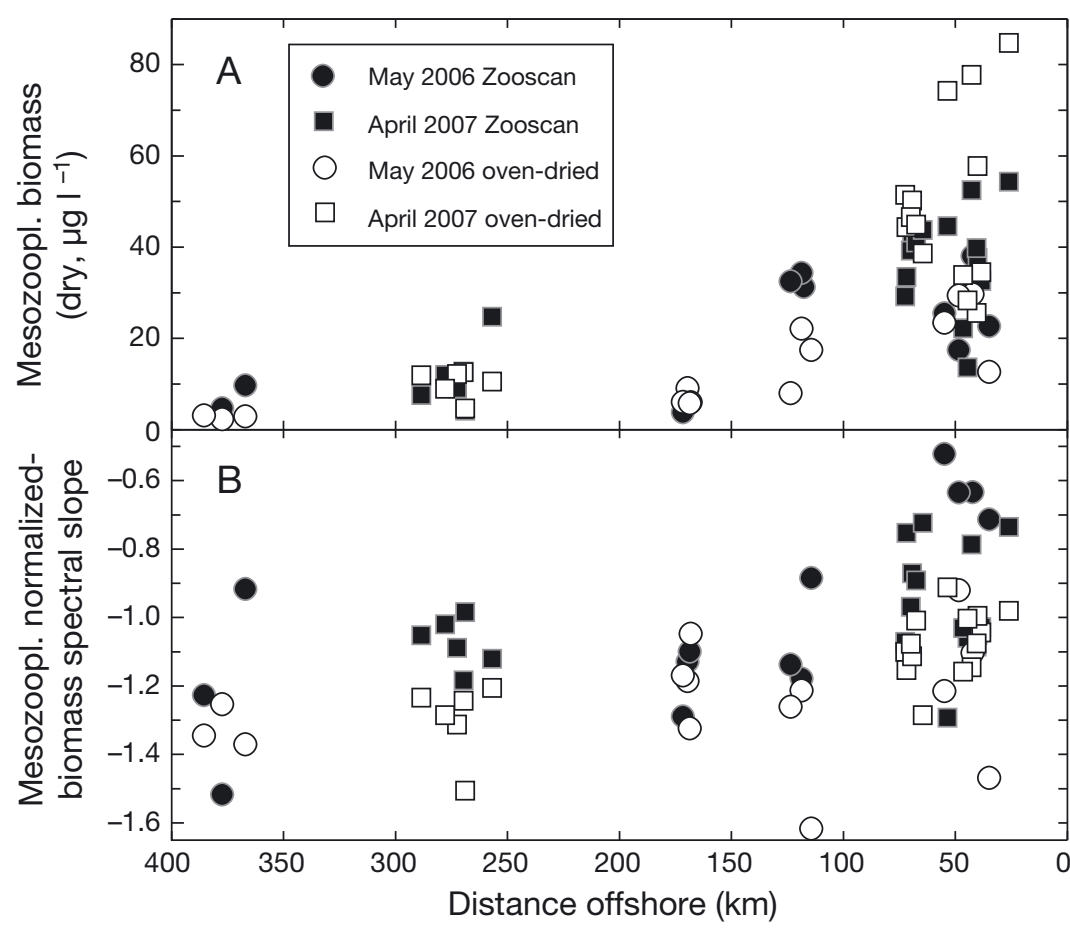

Fig. 5. Mesozooplankton assemblage biomass and size structure estimated by different methods. Solid symbols indicate estimates of Zooscan analysis, as described in the 'Materials and methods'. Open symbols indicate estimates by mesh fractionation and oven drying (Rykaczewski \& Checkley 2008). (A) Estimates of mesozooplankton biomass and (B) normalized-biomass spectral slope show similar trends with distance offshore

Wilcoxon rank-sum tests revealed that only the changes in copepod and chaetognath sizes were significant between the 2 regions. A decrease in the median weight of copepods was strongly associated with a more negative spectral slope of the mesozooplankton assemblage (Fig. 8, Table 3). Changes in taxonomic composition across the ecosystem were relatively minor, with compositions of each taxonomic category differing by only a few percent between grouped eutrophic and oligotrophic samples. However, decreasing spectral slopes were associated with a shift towards a greater contribution of appendicularians and ostracods (Table 4).
What are the implications of the observed relationships between oceanographic conditions and plankton size structure for populations of small pelagic fish? Model-derived estimates of specific growth rates in terms of carbon are displayed in Fig. 9A. Growth rates for anchovy show a distinct maximum in the eutrophic region nearshore, and growth rates decrease as plankter sizes and concentrations are reduced with distance offshore. Growth in the nearshore region is highly variable and strongly dependent on changes in spectral slope; a slight change in the slope results in a considerable increase in the concentration of large zooplankters and has a positive effect on the growth rate of anchovy. This variability decreases offshore, where zooplankton are at low concentrations, and slight changes in concentration and slope are of little benefit to anchovy growth. Between 100 and $150 \mathrm{~km}$ from the coast, estimated growth rates are about $20 \%$ of the nearshore maximum, and growth rates are uniformly negative in the oligotrophic region offshore.

Like anchovy, model-derived estimates of sardine growth rates are also highest inshore of $100 \mathrm{~km}$. However, sardine growth rates are less variable and decline only gradually with distance offshore. Sardine are capable of obtaining their required prey from a wider range of plankter sizes and are less susceptible to changes in the spectral slope of the zooplankton and phytoplankton assemblages in the nearshore region. At 100 to $150 \mathrm{~km}$ offshore, growth rates of sardine are about $50 \%$ of the maximum closer to the coast, and sardine are capable of meeting daily nutrition requirements under some of the prey conditions observed offshore of $250 \mathrm{~km}$.

Table 2. Spearman rank correlation coefficients $(\rho)$ between nutrient concentrations and measurements of the plankton assemblage. Bold values represent correlations with $\mathrm{p}<0.01$. The italicized value represents $\mathrm{p}<0.05$

\begin{tabular}{|lcccc|}
\hline & $\begin{array}{c}\text { Log nitrate } \\
\text { concentration }\end{array}$ & $\begin{array}{c}\text { Phytoplankton } \\
\text { concentration }\end{array}$ & $\begin{array}{c}\text { Phytoplankton } \\
\text { spectral slope }\end{array}$ & $\begin{array}{c}\text { Mesozooplankton } \\
\text { concentration }\end{array}$ \\
\hline Phytoplankton concentration & $\mathbf{0 . 7 4}$ & $\mathbf{0 . 8 4}$ & & \\
Phytoplankton spectral slope & $\mathbf{0 . 7 8}$ & $\mathbf{0 . 7 0}$ & $\mathbf{0 . 5 7}$ & \\
Mesozooplankton concentration & $\mathbf{0 . 7 3}$ & $\mathbf{0 . 6 3}$ & $\mathbf{0 . 5 6}$ & 0.36 \\
Mesozooplankton spectral slope & $\mathbf{0 . 6 7}$ & \\
\hline
\end{tabular}




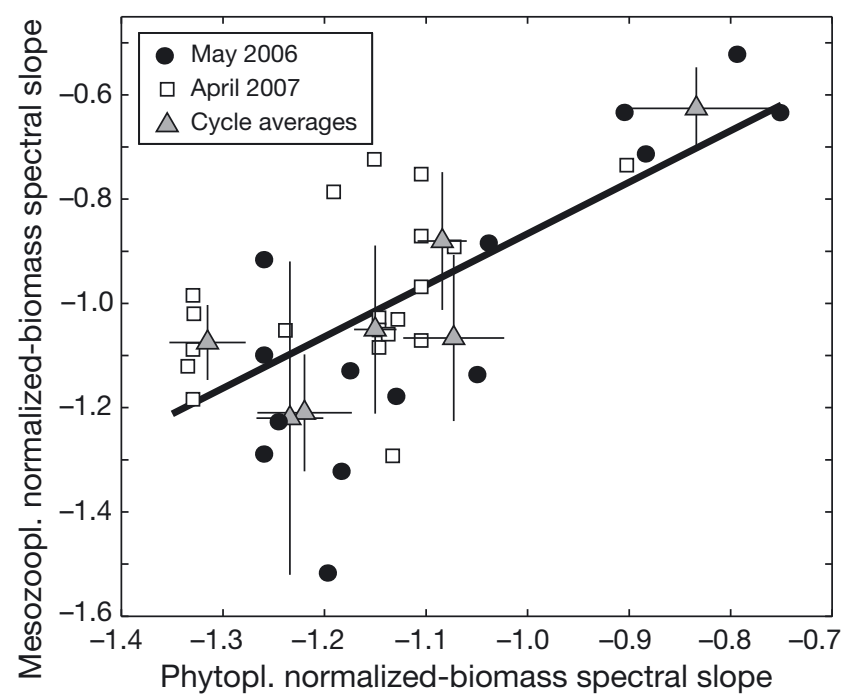

Fig. 6. Comparison of biomass spectral slopes between phytoplankton and mesozooplankton assemblages observed together in the California Current Ecosystem (CCE). The slopes of the mesozooplankton spectra increase with increases in the phytoplankton spectral slope. The line indicates the linear best fit (mesozoopl. slope $=0.99 \times$ phytopl. slope $+0.12, r=0.66, p<0.05$ ). Triangles indicate averages for the 7 experimental cycles with an indication of SD among samples at each location

The distributions of sardine and anchovy eggs were sampled by the National Marine Fisheries Service using a Continuous Underway Fish-Egg Counter (Checkley et al. 2000) during surveys of the California Cooperative Oceanic Fisheries Investigations (CalCOFI) in spring 2006 and 2007. Data from these cruises are displayed in Fig. 9B,C for the transect line corresponding to the zooplankton sampling locations offshore of Pt. Conception, CA. In both years, anchovy eggs were present in the nearshore, eutrophic area and absent from the oligotrophic waters offshore. The opposite is true of the distribution of sardine eggs; sardine eggs were only found in offshore waters.

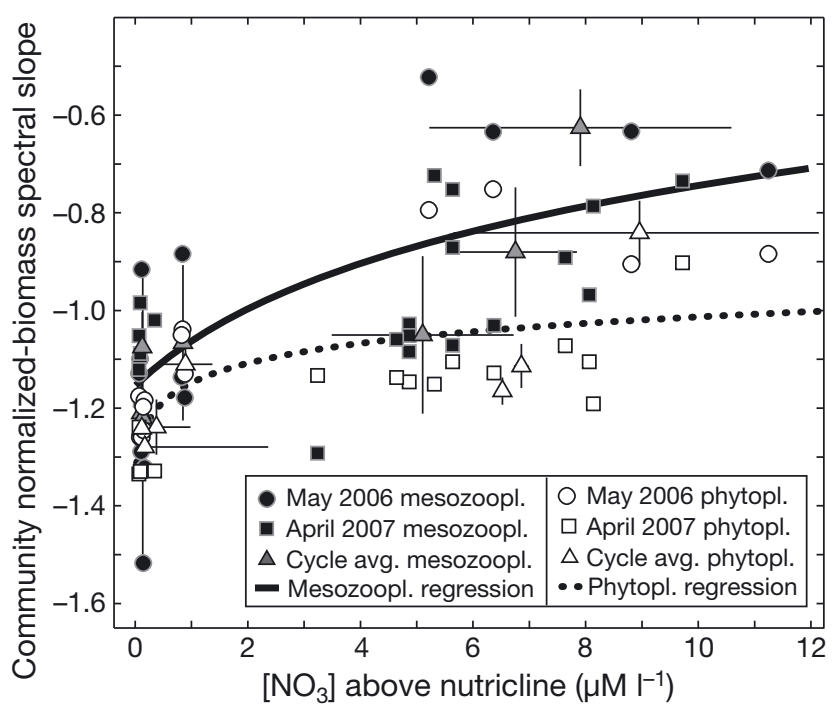

Fig. 7. Estimates of normalized-biomass spectral slopes for phytoplankton and mesozooplankton assemblages observed in the California Current Ecosystem (CCE). The dotted line indicates the logarithmic best-fit line for the relationship between nitrate concentration and phytoplankton spectral slope (slope $\left.=0.06 \ln \left(\left[\mathrm{NO}_{3}\right]+0.05\right)-1.15 ; \mathrm{r}=0.71, \mathrm{p}<0.05\right)$. The solid line is the logarithmic best fit between nitrate concentration and mesozooplankton spectral slope (slope $=0.23$ $\left.x \ln \left(\left[\mathrm{NO}_{3}\right]+2.05\right)-1.32 ; \mathrm{r}=0.66, \mathrm{p}<0.05\right)$. Triangles indicate averages at experimental cycle locations with an indication of SD among samples at each location

\section{DISCUSSION}

\subsection{Size structure of zooplankton and phytoplankton assemblages}

The covariability of upwelling rate, density, and nitrate concentration describes a gradient of conditions between 2 distinct regions: (1) the eutrophic area nearshore where coastal upwelling and high levels of curl-driven upwelling promote shoaling of the nutricline, and (2) a relatively oligotrophic region offshore where winds and curl-driven upwelling are

Table 3. Median dry weights of individual zooplankters and Spearman rank correlation coefficients ( $\rho)$ between mesozooplankton normalized-biomass spectral slopes and the median weights of major taxonomic groups. The SD observed for each group is noted in parentheses. Wilcoxon rank-sum tests were used to investigate changes between oligotrophic and eutrophic stations. Bold values represent tests with $\mathrm{p}<0.01$. Italicized values represent $\mathrm{p}<0.05$. Eutrophic and oligotrophic samples were grouped according to nitrate concentration above the nutricline, with the nearshore group composed of samples with nitrate values greater than $1.0 \mu \mathrm{M} \mathrm{I}^{-1}$

\begin{tabular}{|lcccc|}
\hline $\begin{array}{l}\text { Taxonomic } \\
\text { group }\end{array}$ & $\begin{array}{c}\text { Eutrophic median } \\
\text { weight, } \mu \text { g (SD) }\end{array}$ & $\begin{array}{c}\text { Oligotrophic median } \\
\text { weight, } \mu \text { (SD) }\end{array}$ & $\begin{array}{c}\text { Significant difference } \\
\text { (Wilcoxon rank-sum) }\end{array}$ & $\begin{array}{c}\rho \text { (median weight } \\
\text { with slope; Spearman) }\end{array}$ \\
\hline Copepods & $18.8(2.9)$ & $15.9(2.5)$ & Yes & $\mathbf{0 . 8 8}$ \\
Euphausiids & $914(1400)$ & $415(450)$ & No & 0.13 \\
Chaetognaths & $117(150)$ & $40.2(22)$ & Yes & 0.24 \\
Appendicularians & $18.0(8.2)$ & $15.2(6.8)$ & No & -0.28 \\
Ostracods & $37.0(24)$ & $40.9(30)$ & No & 0.01 \\
\hline
\end{tabular}


Table 4. Taxonomic composition and Spearman rank correlation coefficients ( $\rho$ ) between total mesozooplankton biomass and relative contributions of major taxonomic groups. Wilcoxon rank-sum tests were used to investigate changes between oligotrophic and eutrophic stations. The SD observed for each group is noted in parentheses. Bold values represent tests with $\mathrm{p}<0.01$. Italicized values represent $\mathrm{p}<0.05$

\begin{tabular}{|lcccr|}
\hline $\begin{array}{l}\text { Taxonomic } \\
\text { group }\end{array}$ & $\begin{array}{c}\text { Inshore composition, } \\
\text { \% (SD) }\end{array}$ & $\begin{array}{c}\text { Offshore composition } \\
\% \text { (SD) }\end{array}$ & $\begin{array}{c}\text { Significant difference } \\
\text { (Wilcoxon rank-sum) }\end{array}$ & $\begin{array}{c}\rho \text { (composition } \\
\text { with slope) }\end{array}$ \\
\hline Copepods & $92.9(2.9)$ & $89.2(5.2)$ & Yes & 0.28 \\
Euphausiids & $5.79(5.8)$ & $3.65(3.0)$ & No & 0.09 \\
Chaetognaths & $3.04(2.5)$ & $6.73(4.8)$ & Yes & -0.29 \\
Appendicularians & $0.079(0.06)$ & $1.61(3.5)$ & Yes & $-\mathbf{0 . 5 3}$ \\
Ostracods & $1.07(0.51)$ & $1.41(0.62)$ & No & -0.37 \\
\hline
\end{tabular}

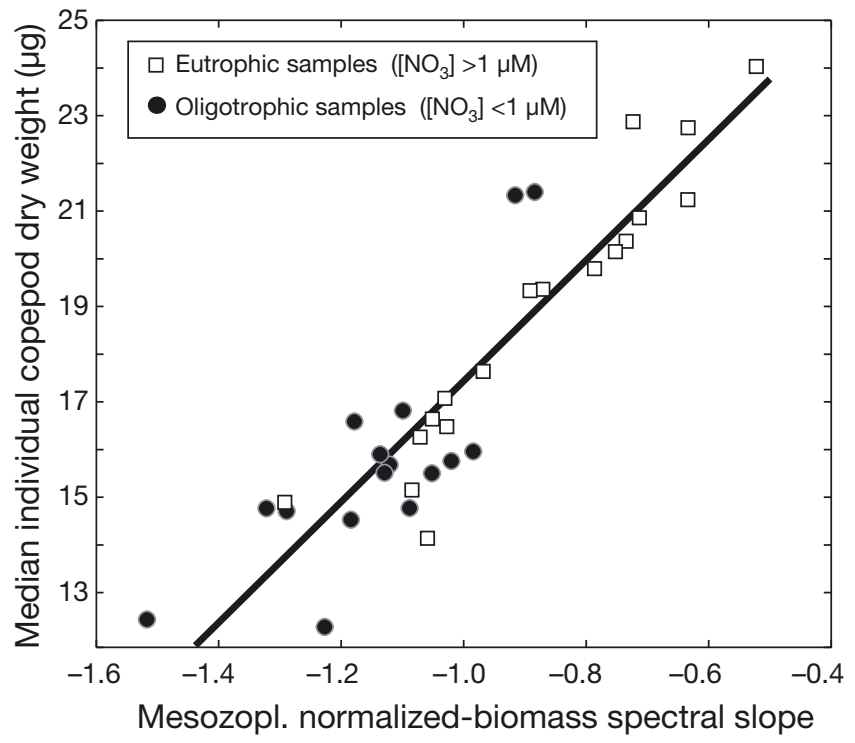

Fig. 8. Median dry weights of individual copepods in relation to the spectral slope of the mesozooplankton assemblage. Copepods were the most dominant taxa present in both oligotrophic and eutrophic samples, and changes in the sizes of individual copepods were largely responsible for the changes observed in spectral slope. The dark line is the linear best fit (individual weight $=12.7 \times$ slope $+30.1 ; \mathrm{r}=0.91$,

$$
\mathrm{p}<0.05)
$$

weak or negative and nutrient concentrations are low. These regions were clearly separated in May 2006 when the wind stress maximum and minimum in curl-driven upwelling were located $125 \mathrm{~km}$ from shore. A distinct separation was not as clearly resolved in April 2007, but satellite scatterometry and ocean color indicate that the wind stress maximum, positive curl-driven upwelling, and higher levels of chl $a$ extended further offshore in April 2007 than in May 2006. This contrast between nearshore productive waters with more oligotrophic waters offshore is typical of conditions found in eastern-boundary current ecosystems during the upwelling season (Huyer 1983).
A distinct separation between the nearshore and offshore environments was also evident in the biomass spectra of phytoplankton and mesozooplankton assemblages (Figs. $3 \&$ 5, Table 3). Larger zooplankters were relatively more abundant in eutrophic areas where the spectral slopes of phytoplankton assemblages were greatest, and the contribution of these large individuals to total biomass decreased as nutrient levels decreased (Fig. 7). Increases in nutrients had a greater influence on the slope of the biomass spectra when nutrient concentrations were low. Increases in nutrient concentration had a lesser effect on the spectral slopes of phytoplankton and zooplankton assemblages in eutrophic areas.

In addition to the difference in the physical conditions and nitrate concentrations that characterize these regions of large and small individual sizes, there is increasing evidence that phytoplankton assemblages in offshore regions of the CCE are iron limited (King \& Barbeau 2007). The nearshore environments sampled in 2006 and 2007 were not iron limited (King \& Barbeau 2011), likely because these waters were recently in close proximity to the benthic-boundary layer along the continental shelf where trace metals are abundant. Along with differences in physical conditions and nitrate concentrations, differential supply of these trace metals to the nearshore and offshore environments is also a factor which may influence the size structure of plankton assemblages.

At each cycle location, the variability of the spectral slopes of the zooplankton assemblage was greater than those of the phytoplankton assemblage. A greater variability in the structure of the zooplankton assemblage relative to chl a concentration has been noted in previous studies of the CCE (Star \& Mullin 1981). Zooplankters, in comparison to phytoplankters, have greater ability to swim vertically and control their position in the water column. Such behavior, when coupled with the dynamic, advective 

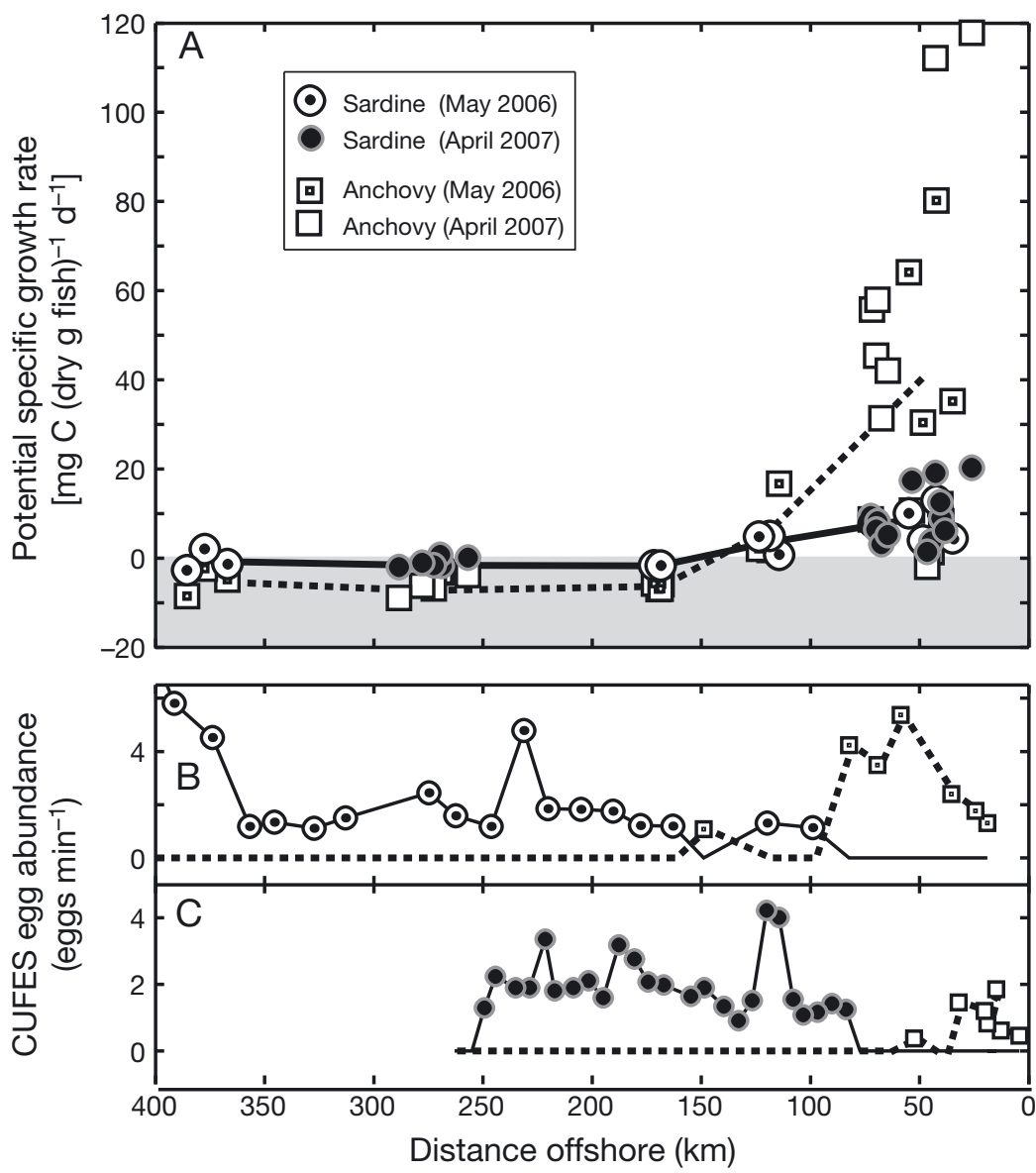

Fig. 9. Potential specific growth rate of individual sardine and anchovy for the plankton conditions observed during cruises in May 2006 and April 2007 off of Pt. Conception, CA, and egg distributions of the 2 species observed during spring CalCOFI cruises. (A) Solid (representing sardine) and dotted (anchovy) black lines connect averages at $50 \mathrm{~km}$ intervals using data from both years. The shaded region indicates the region of negative growth. Distributions of sardine and anchovy eggs off of Pt. Conception are shown for CalCOFI cruises in (B) spring 2006 and (C) 2007 as sampled by the Continuous Underway Fish Egg Counter (CUFES). Note the absence of anchovy eggs is approximately coincident with the location of negative growth rate for anchovy. Sardine eggs are distributed widely in the offshore region where there is some potential for positive growth. Eggs were not sampled offshore of $250 \mathrm{~km}$ in spring 2007

flow present in upwelling regions, may result in greater aggregation (i.e. patchiness) in vertical and horizontal dimensions (Franks 1992) and explain the increased variability in estimates of zooplankton size structure at each location. Variability in the zooplankton biomass and spectral slope was highest in the nearshore environment (Fig. 5), consistent with previous observations of increased patchiness in eutrophic regions of the CCE (Venrick 1972, Star \& Mullin 1981).

What underlying principles may be responsible for the apparent relationship between the structure of phytoplankton and zooplankton assemblages? Poulin
\& Franks (2010) demonstrated that such relationships may emerge for a variety of reasons dependent on the allometric scaling of biological rates and the assumption that the size ratio between phytoplankton prey and zooplankton predators is applicable across the spectrum of size classes. The results of Moloney \& Field (1991) and Hansen et al. (1994) demonstrated that the predator:prey ratio is remarkably consistent over a wide range of sizes within a certain taxon. However, if large changes in the taxonomic composition of the zooplankton result from changes in phytoplankton concentration or nutrient content, a clear relationship between phytoplankton and zooplankton size structure may be obscured by changes in the size ratio between predators and prey. Major changes in gross taxonomic composition were not observed across the trophic gradient examined here (Table 4). Variability in spectral slope was strongly associated with changes in the individual sizes of copepods (Table 3) rather than with changes in the gross taxonomic composition, and a conceptual model relating phytoplankton and zooplankton size structure through predator-prey interactions appears to be appropriate.

An important caveat to the conclusions presented above concerns the lack of consideration of zooplankters smaller than $8 \mu \mathrm{g}$ dry weight. This includes the naupliar and copepodite stages of numerous copepod species present in the CCE. Here, I deliberately focus on the mesozooplankton assemblage collected by a $202 \mu \mathrm{m}$ mesh bongo net. Assessment of the contribution of smaller individuals to the zooplankton assemblage was prevented by their incomplete retention by the plankton net used in this study. Increased contribution of early developmental stages of zooplankton to the eutrophic nearshore assemblage is a valid hypothesis, as egg production is often considered to be food-limited in the marine environment (Checkley 1980, Runge 1985). However, complete populations of small species were certainly disregarded as well. Given the results presented above, it is plausible that the contribution of small species 
and their developmental stages increases in oligotrophic environments, and the observed decrease in mesozooplankton spectral slope with decreasing nutrient concentration may be robust despite the fact that smaller individuals were not considered here.

\subsection{Potential for growth by small pelagic fish}

In the CCE, annual estimates of growth in the anchovy population are high and variable in comparison to that of the sardine population (Jacobson et al. 2001). Instantaneous surplus production rates for anchovy range from -0.5 to 1.5 with a standard deviation of 0.68 . Instantaneous surplus production rates for sardine range from -0.4 to 0.8 with a standard deviation of 0.46 (Jacobson et al. 2001). These differences in population growth rates are reflected in the estimates of growth rates by individuals of each taxon displayed in Fig. 9A. For the spectrum of plankton assemblages examined in the CCE, individual growth rate of anchovy averaged at each cycle location ranged from -9 to $75 \mathrm{mg} \mathrm{C}$ (dry g fish) $)^{-1} \mathrm{~d}^{-1}$ with a standard deviation of $22 \mathrm{mg} \mathrm{C}$ (dry g fish) ${ }^{-1}$ $\mathrm{d}^{-1}$. Sardine growth rates ranged from -3 to $16 \mathrm{mg} \mathrm{C}$ (dry $\mathrm{g}$ fish) $)^{-1} \mathrm{~d}^{-1}$ with a standard deviation of $5 \mathrm{mg} \mathrm{C}$ (dry $g$ fish) $)^{-1} \mathrm{~d}^{-1}$. Results, in terms of nitrogen budgets, exhibited similar characteristics with distance offshore. These results are supported by observations of distinct habitat areas measured by the distribution of pelagic eggs (Fig. 9B,C; Checkley et al. 2000) and further substantiate the idea that variability in the biomass of sardine and anchovy populations may be related to the size structure of the zooplankton assemblage (van der Lingen et al. 2009) and changes in the productivity of eutrophic and oligotrophic environments over time (Rykaczewski \& Checkley 2008).

The absence of sardine eggs in the nearshore region where the potential for individual growth is highest is puzzling. However, this exercise considered only 1 aspect of fish habitat - the availability of prey. The lack of sardine eggs nearshore may indicate either active avoidance of nearshore regions where predation on eggs may be high and/or low temperatures may limit growth physiologically. Predation on sardine eggs by large zooplankters has been hypothesized to explain observations of complimentary distributions of euphausiids and sardine eggs (Checkley et al. 2000). Sardine lose little in terms of potential growth by avoiding the eutrophic, nearshore area where zooplankton biomass and predation on eggs and larvae are higher. The situation for anchovy is different; avoidance of the nearshore region would greatly reduce potential growth (Fig. 9). Observations that sardines of the eastern Pacific are able to prosper during warm, El Niño periods when production by other species declines led Bakun \& Broad (2003) to suggest that sardine exploit an 'ecological loophole' - under relatively oligotrophic conditions, sardine populations are sustained by their ability to consume small, planktonic prey, while populations of other taxa, including the predators on the eggs and larvae of sardine, decline. The estimates of specific growth rates presented here support the loophole hypothesis and suggest that it is broadly applicable in describing the growth conditions for small pelagic fish across the large ecosystem and not restricted to comparisons of extremes in oceanographic conditions as during El Niño and La Niña periods.

Estimated growth rates presented in Fig. 9A are useful for comparison of the habitat available for individual growth, but it is important to stress that these values are potential specific growth rates, representing the upper bound to the daily growth (reproductive and somatic) attainable by adult fish during the most productive period of the year. The laboratory examinations of fish feeding on which the bioenergetics models are based were conducted over feeding periods of several ( 2 to 3 ) hours, and the nitrogen and carbon budgets derived from these examinations may not be accurately extrapolated to describe growth processes for longer periods of feeding (James et al. 1989, van der Lingen 1999). The growth rate estimates are based on the portions of the phytoplankton and zooplankton assemblages that were retained on a $0.7 \mu \mathrm{m}$ glass fiber filter and in a $202 \mu \mathrm{m}$ mesh bongo net, respectively. Zooplankton that are not retained by a $202 \mu \mathrm{m}$ mesh net were not considered as potential diet of anchovy and sardine, and the lack of consideration of these smaller size classes of zooplankton may lead to an underestimation of the potential growth rates. This bias may be more relevant for sardine, since the filtering rates on sizes of zooplankton less than $202 \mu \mathrm{m}$ in length are greater for sardine than for anchovy (van der Lingen et al. 2006). Furthermore, the rates estimated here do not address seasonal variability in plankton assemblages and inter- and intraspecific competition for resources.

The average specific growth rates of anchovy in the nearshore region was estimated to be about $75 \mathrm{mg} \mathrm{C}$ (dry $g$ fish) ${ }^{-1} \mathrm{~d}^{-1}$, requiring a prey consumption of $107 \mathrm{mg} \mathrm{C}$ (dry g fish) $)^{-1} \mathrm{~d}^{-1}$. Consider a population size of 1 million metric tons - about half the maximal 
estimated biomass during the late 1960s to early 1980s (Thayer et al. 2017) - ranging over an area of $40 \times 10^{3} \mathrm{~km}^{2}$, the approximate area of the Southern California Bight. If we assume a dry weight:wet weight ratio of 0.3 (James et al. 1989), adult anchovy would consume $0.40 \mathrm{~g} \mathrm{C} \mathrm{m}^{-2} \mathrm{~d}^{-1}$ of zooplankton. Assuming (1) that anchovy feed at the second trophic level, (2) a generous $20 \%$ conversion efficiency from primary to secondary production and (3) an annually averaged net primary production of $1 \mathrm{~g} \mathrm{C} \mathrm{m}^{-2} \mathrm{~d}^{-1}$ (Mantyla et al. 1995), this level of anchovy consumption would be equivalent to $400 \%$ of the available secondary production - a level certainly not attainable on a regular basis. Realized growth rates (somatic and reproductive) for adult anchovy are much lower than the potential rates estimated here; Hunter \& Leong (1981) estimated realized anchovy growth rates at about $6.5 \mathrm{mg}$ (dry $\mathrm{g}$ fish) $)^{-1} \mathrm{~d}^{-1}$. The majority of this growth is devoted to reproduction. Assuming a carbon:dry weight ratio of 0.44 for fish (Watanabe \& Saito 1998), this growth rate is equivalent to $2.9 \mathrm{mg} \mathrm{C}$ (dry $g$ fish $)^{-1} \mathrm{~d}^{-1}$. This realized level of growth requires a consumption $14.0 \mathrm{mg} \mathrm{C}$ (dry g fish) ${ }^{-1} \mathrm{~d}^{-1}$. Based on a population size of 1 million metric tons over an area of $40 \times 10^{3} \mathrm{~km}^{2}$ and the 3 assumptions noted above, this consumption rate is equivalent to $52 \%$ of the secondary production. Even given this lower estimate of anchovy growth rate, the prey fields observed across the CCE suggest this level of growth may be attainable only in eutrophic environments.

Somatic growth in adult sardine continues after maturity and exceeds the rate of reproductive growth until about age 5 (Hill et al. 2017). Lasker (1970) estimated total specific growth rate for adult sardine at $1.5 \mathrm{mg}$ (dry g fish) ${ }^{-1} \mathrm{~d}^{-1}$, equivalent to $0.65 \mathrm{mg} \mathrm{C}$ (dry $g$ fish $)^{-1} \mathrm{~d}^{-1}$ and requiring a prey consumption rate of $6.7 \mathrm{mg} \mathrm{C}$ (dry $\mathrm{g}$ fish) $)^{-1} \mathrm{~d}^{-1}$. Given the prey field observed in the CCE, this level of growth is occasionally attainable in oligotrophic, offshore waters as well as in the more productive waters nearshore. In the recent decade, the adult population of sardine reached an estimated biomass of 2 million metric tons (Hill et al. 2017). If we assume, for sake of comparison, that this population ranged over an area equal to $40 \times 10^{3} \mathrm{~km}^{2}$, the adult sardine population would require about $50 \%$ of the available secondary production.

These estimates of the secondary production required to support fish growth are subject to assumptions concerning levels of primary production, the spatial distribution of each population, and the trophic transfer efficiency between primary and secondary producers. The distributions of both sardine and anchovy expand in distribution to the north and offshore of the Southern California Bight, especially during periods of greatest biomass (MacCall 1990), likely occupying an area greater than $40 \times 10^{3} \mathrm{~km}^{2}$. In addition, sardine (and anchovy, to a lesser degree) are omnivorous, supplementing their diet of zooplankton with phytoplankton (van der Lingen et al. 2009). It is also important to note that the zooplankters, which serve as the main prey items for both taxa, are themselves omnivorous. Consideration of a larger spatial distribution and omnivory by fish would act to decrease the portion of secondary production required to support the populations of sardine and anchovy, while decreasing the trophic transfer efficiency from $20 \%$ or considering some degree of omnivory by zooplankton would increase the portion of secondary production required. Furthermore, all secondary production is not equally prone to predation by the planktivorous fishes; the size-selective predation by anchovy would disproportionately affect larger zooplankters.

\section{CONCLUSIONS}

Spectral slopes of zooplankton assemblages decline with distance offshore in concert with phytoplankter sizes, nutrient concentrations, and physical conditions promoting shoaling of the pycnocline. These observations are consistent with the hypothesis that changes in the biomass and size structure of the zooplankton assemblage are related to the availability of phytoplankton resources. Changes in the size spectra of the zooplankton appear to be dominated by variation in the individual biomasses of copepods rather than by changes in the gross taxonomic composition of the zooplankton assemblage.

Plankton concentrations and size structures have important implications for dominant populations of planktivorous fish found in upwelling ecosystems worldwide. The combinations of zooplankter sizes and concentrations observed in the CCE during spring 2006 and 2007 suggest that adult anchovy may be restricted to the eutrophic habitat in which daily nutritional requirements are met, even during the upwelling season when primary production is highest. Sardine growth is less dependent on the nearshore environment. These results are consistent with previous descriptions of sardine and anchovy ecology which suggest that anchovy are opportunistic specialists, taking advantage of highly productive conditions when available but being incapable of sustenance during periods of low productivity. The 
strategy of sardine is that of a generalist, being less able to exploit periods of high productivity, but able to meet daily nutritional requirements under moderately oligotrophic conditions. The hypothesis that emerges is interesting. Variability in the size structure and abundance of zooplankters in the more oligotrophic waters of the CCE has the potential to influence production of sardine; changes in the zooplankton may promote either positive or negative growth. These changes in the oligotrophic area do not influence anchovy, as growth is uniformly negative over the range of zooplankton assemblages observed. However, the situation is nearly reversed in the eutrophic environment. Changes in the nearshore zooplankton assemblage strongly influence the potential for anchovy production, while the potential for sardine growth remains relatively constant. Changes in the offshore wind stress and wind-stress curl may have a substantial impact on the suitable habitat and growth rate of sardine, while coastal, alongshore wind stress and other nearshore processes may have a stronger influence on anchovy populations.

Acknowledgements. Funding for this work was provided by NSF Division of Ocean Sciences Award no. 1434530, NASA Carbon Cycle \& Ecosystems Award no. NX07AO31H, and the San Diego chapter of the ARCS Foundation. I thank R. Goericke for graciously providing the size-fractionated phytoplankton data and the CalCOFI Program for conducting regular surveys of ichthyoplankton. The zooplankton analysis presented would have been much more difficult without the help of M. Ohman, J. B. Romagnan, and A. Townsend. I thank D. Checkley and A. Pasulka for their comments on the manuscript. Cruises in 2006 and 2007 were supported by the CCE Long-Term Ecological Research Program (NSF Division of Ocean Sciences Award no. 0417616).

\section{LITERATURE CITED}

Alheit J, Niquen M (2004) Regime shifts in the Humboldt Current ecosystem. Prog Oceanogr 60:201-222

* Ayón P, Swartzman G, Espinoza P, Bertrand A (2011) Longterm changes in zooplankton size distribution in the Peruvian Humboldt Current System: conditions favouring sardine or anchovy. Mar Ecol Prog Ser 422:211-222

Bakun A, Broad K (2003) Environmental 'loopholes' and fish population dynamics: comparative pattern recognition with focus on El Niño effects in the Pacific. Fish Oceanogr 12:458-473

Benfield MC, Grosjean P, Culverhouse PF, Irigoien X and others (2007) RAPID: research on automated plankton identification. Oceanography 20:172-187

Breiman L (2001) Random forests. Mach Learn 45:5-32

Brett JR, Groves TDD (1979) Physiological energetics. In: Hoar WS, Randall DJ, Brett JR (eds) Fish physiology: bioenergetics and growth, Book 8. Academic Press, New York, NY, p 279-352
Buitenhuis E, Le Quere C, Aumont O, Beaugrand G and others (2006) Biogeochemical fluxes through mesozooplankton. Global Biogeochem Cycles 20:GB2003

Chao Y, Li ZJ, Kindle JC, Paduan JD, Chavez FP (2003) A high-resolution surface vector wind product for coastal oceans: blending satellite scatterometer measurements with regional mesoscale atmospheric model simulations. Geophys Res Lett 30:1013

Checkley DM (1980) Food limitation of egg production by a marine, planktonic copepod in the sea off southern California. Limnol Oceanogr 25:991-998

Checkley DM Jr, Dotson RC, Griffith DA (2000) Continuous, underway sampling of eggs of Pacific sardine (Sardinops sagax) and northern anchovy (Engraulis mordax) in spring 1996 and 1997 off Southern and Central California. Can J Fish Aquat Sci 47:1139-1155

* Checkley DM, Davis RE, Herman AW, Jackson GA, Beanlands B, Regier LA (2008) Assessing plankton and other particles in situ with the SOLOPC. Limnol Oceanogr 53: 2123-2136

*Checkley DM, Asch RG, Rykaczewski RR (2017) Climate, anchovy, and sardine. Annu Rev Mar Sci 9:469-493

Chisholm SW (1992) Phytoplankton size. In: Falkowski PG, Woodhead AD (eds) Primary productivity and biogeochemical cycles in the sea. Plenum, New York, NY, p 213-237

Emmett RL, Brodeur RD, Miller TW, Pool SS, Krutzikowsky GK, Bentley PJ, McCrae J (2005) Pacific sardine (Sardinops sagax) abundance, distribution, and ecological relationships in the Pacific Northwest. Calif Coop Ocean Fish Invest Rep 46:122-143

F Franks PJS (1992) Sink or swim: accumulation of biomass at fronts. Mar Ecol Prog Ser 82:1-12

Frost BW (1974) Feeding processes at lower trophic levels in pelagic communities. In: Miller CB (ed) The biology of the oceanic Pacific. Oregon State University Press, Corvallis, OR, p 59-77

Gillooly JF (2000) Effect of body size and temperature on generation time in zooplankton. J Plankton Res 22:241-251

* Gonzalez-Quiros R, Checkley DM (2006) Occurrence of fragile particles inferred from optical plankton counters used in situ and to analyze net samples collected simultaneously. J Geophys Res Oceans 111:C05S06

Gorsky G, Ohman MD, Picheral M, Gasparini S and others (2010) Digital zooplankton image analysis using the ZooScan integrated system. J Plankton Res 32:285-303

* Grosjean P, Picheral M, Warembourg C, Gorsky G (2004) Enumeration, measurement, and identification of net zooplankton samples using the ZOOSCAN digital imaging system. ICES J Mar Sci 61:518-525

Hansen B, Bjornsen PK, Hansen PJ (1994) The size ratio between planktonic predators and their prey. Limnol Oceanogr 39:395-403

Harris R, Wiebe P, Lenz J, Skjoldal HR, Huntley M (2000) ICES zooplankton methodology manual. Academic Press, San Diego, CA

Hill K, Crone P, Zwolinski J (2017) Assessment of the Pacific sardine resource in 2017 for US management in 20172018. April 2017 Briefing Book. Pacific Fishery Management Council, Portland, OR

Holm-Hansen O, Lorenzen C, Holmes R, Strickland J (1965) Fluorometric determination of chlorophyll. ICES J Mar Sci 30:3-15

*Hopcroft RR, Roff JC, Lombard D (1998) Production of tropical copepods in Kingston Harbour, Jamaica: the impor- 
tance of small species. Mar Biol 130:593-604

Hopcroft RR, Clarke C, Chavez FP (2002) Copepod communities in Monterey Bay during the 1997-1999 El Niño and La Niña. Prog Oceanogr 54:251-264

Hunter JR, Leong R (1981) The spawning energetics of female northern anchovy, Engraulis mordax. Fish Bull 79:215-230

Huyer A (1983) Coastal upwelling in the California current system. Prog Oceanogr 12:259-284

Ikeda T, Kanno Y, Ozaki K, Shinada A (2001) Metabolic rates of epipelagic marine copepods as a function of body mass and temperature. Mar Biol 139:587-596

Irigoien X, Fernandes JA, Grosjean P, Denis K, Albaina A, Santos M (2009) Spring zooplankton distribution in the Bay of Biscay from 1998 to 2006 in relation with anchovy recruitment. J Plankton Res 31:1-17

Jacobson LD, De Oliveira JAA, Barange M, Cisneros-Mata MA and others (2001) Surplus production, variability, and climate change in the great sardine and anchovy fisheries. Can J Fish Aquat Sci 58:1891-1903

James AG (1987) Feeding ecology, diet and field-based studies on feeding selectivity of the Cape anchovy Engraulis capensis Gilchrist. S Afr J Mar Sci 5:673-692

James AG (1988) Are clupeid microphagists herbivorous or omnivorous? A review of the diets of some commercially important clupeids. S Afr J Mar Sci 7:161-177

James AG, Findlay KP (1989) Effect of particle size and concentration on feeding behavior, selectivity and rates of food ingestion by the Cape anchovy Engraulis capensis. Mar Ecol Prog Ser 50:275-294

James AG, Probyn T, Hutchings L (1989) Laboratoryderived carbon and nitrogen budgets for the omnivorous planktivore Engraulis capensis Gilchrist. J Exp Mar Biol Ecol 131:125-145

King AL, Barbeau K (2007) Evidence for phytoplankton iron limitation in the southern California Current System. Mar Ecol Prog Ser 342:91-103

King AL, Barbeau KA (2011) Dissolved iron and macronutrient distributions in the southern California Current System. J Geophys Res Oceans 116:C03018

Kobari T, Nagaki T, Takahashi K (2004) Seasonal changes in abundance and development of Calanus pacificus (Crustacea: Copepoda) in the Oyashio-Kuroshio Mixed Region. Mar Biol 144:713-721

Koslow JA (1981) Feeding selectivity of schools of northern anchovy, Engraulis mordax, in the Southern California Bight. Fish Bull 79:131-142

Landry MR, Ohman MD, Goericke R, Stukel MR, Tsyrklevich K (2009) Lagrangian studies of phytoplankton growth and grazing relationships in a coastal upwelling ecosystem off Southern California. Prog Oceanogr 83: 208-216

Lasker R (1970) Utilization of zooplankton energy by a Pacific sardine population in the Californian Current. In: Steele JH (ed) Marine food chains. University of California Press, Los Angeles, CA, p 265-284

Lavaniegos BE, Ohman MD (2007) Coherence of long-term variations of zooplankton in two sectors of the California Current System. Prog Oceanogr 75:42-69

* Legendre L, Michaud J (1998) Flux of biogenic carbon in oceans: size-dependent regulation by pelagic food webs. Mar Ecol Prog Ser 164:1-11

K Leong RJH, O'Connell CP (1969) A laboratory study of particulate and filter feeding of northern anchovy (Engraulis mordax). J Fish Res Board Can 26:557-582
Lindley JA, Robins DB, Williams R (1999) Dry weight carbon and nitrogen content of some euphausiids from the north Atlantic Ocean and the Celtic Sea. J Plankton Res 21: 2053-2066

Kouw GG, Van der Lingen CD, Gibbons MJ (1998) Differential feeding by sardine Sardinops sagax and anchovy Engraulis capensis recruits in mixed shoals. S Afr J Mar Sci 19:227-232

MacCall AD (1990) Dynamic geography of marine fish populations. Washington University Press, Seattle, WA

Manriquez K, Escribano R, Hidalgo P (2009) The influence of coastal upwelling on the mesozooplankton community structure in the coastal zone off Central/Southern Chile as assessed by automated image analysis. J Plankton Res 31:1075-1088

Mantyla AW, Venrick EL, Hayward TL (1995) Primary production and chlorophyll relationships, derived from ten years of CalCOFI measurements. Calif Coop Ocean Fish Invest Rep 36:159-166

* Medellin-Mora J, Escribano R, Schneider W (2016) Community response of zooplankton to oceanographic changes (2002-2012) in the central/southern upwelling system of Chile. Prog Oceanogr 142:17-29

*Moloney CL, Field JG (1991) The size-based dynamics of plankton food webs. 1. A simulation-model of carbon and nitrogen flows. J Plankton Res 13:1003-1038

* Morel FMM, Hudson RJM, Price NM (1991) Limitation of productivity by trace-metals in the sea. Limnol Oceanogr 36:1742-1755

Mullin MM (1998) Biomasses of large-celled phytoplankton and their relation to the nitricline and grazing in the California current system off southern California, 19941996. Calif Coop Ocean Fish Invest Rep 39:117-123

* Mullin MM, Sloan PR, Eppley RW (1966) Relationship between carbon content, cell volume, and area in phytoplankton. Limnol Oceanogr 11:307-311

* O'Connell CP (1972) The interrelation of biting and filtering in the feeding activity of the northern anchovy (Engraulis mordax). J Fish Res Board Can 29:285-293

*Peck MA, Reglero P, Takahashi M, Catalán IA (2013) Life cycle ecophysiology of small pelagic fish and climate-driven changes in populations. Prog Oceanogr 116:220-245

Platt T, Denman K (1978) The structure of pelagic marine ecosystems. Rapp PV Reùn Cons Int Explor Mer 173: 60-65

พ Poulin FJ, Franks PJS (2010) Size-structured planktonic ecosystems: constraints, controls and assembly instructions. J Plankton Res 32:1121-1130

* Riegman R, Kuipers BR, Noordeloos AAM, Witte HJ (1993) Size-differential control of phytoplankton and the structure of plankton communities. Neth J Sea Res 31: 255-265

* Rodríguez J, Tintoré J, Allen JT, Blanco JM and others (2001) Mesoscale vertical motion and the size structure of phytoplankton in the ocean. Nature 410:360-363

Runge JA (1985) Relationship of egg production of Calanus pacificus to seasonal changes in phytoplankton availability in Puget Sound, Washington. Limnol Oceanogr 30: 382-396

Kykaczewski RR, Checkley DM (2008) Influence of ocean winds on the pelagic ecosystem in upwelling regions. Proc Natl Acad Sci USA 105:1965-1970

Satapoomin S (1999) Carbon content of some common tropical Andaman Sea copepods. J Plankton Res 21: $2117-2123$ 
Schwartzlose RA, Alheit J, Bakun A, Baumgartner TR and others (1999) Worldwide large-scale fluctuations of sardine and anchovy populations. S Afr J Mar Sci 21: 289-347

Smith RL (1968) Upwelling. Oceanogr Mar Biol Annu Rev 6: 11-46

Star JL, Mullin MM (1981) Zooplanktonic assemblages in three areas of the North Pacific as revealed by continuous horizontal transects. Deep-Sea Res A 28:1303-1322

Strickland JDH (1960) Measuring the production of marine phytoplankton. Bull Fish Res Board Can 122:1-172

Taylor AG, Landry MR, Selph KE, Wokuluk JJ (2015) Temporal and spatial patterns of microbial community biomass and composition in the Southern California Current Ecosystem. Deep Sea Res II 112:117-128

Thayer J, Maccall A, Sydeman W, Davison P (2017) California anchovy population remains low, 2012-16. Calif Coop Ocean Fish Invest Rep 58:1-8

Uye S (1982) Length-weight relationships of important zooplankton from the Inland Sea of Japan. J Oceanogr Soc Jpn 38:149-158

van der Lingen CD (1994) Effect of particle size and concentration on the feeding behaviour of adult pilchard Sardinops sagax. Mar Ecol Prog Ser 109:1-13

van der Lingen CD (1995) Respiration rate of adult pilchard Sardinops sagax in relation to temperature, voluntary swimming speed and feeding behaviour. Mar Ecol Prog

Editorial responsibility: Myron Peck, Hamburg, Germany
Ser 129:41-54

*van der Lingen CD (1998) Gastric evacuation, feeding periodicity and daily ration of sardine Sardinops sagax in the southern Benguela upwelling ecosystem. S Afr J Mar Sci 19:305-316

van der Lingen CD (1999) The feeding ecology of, and carbon and nitrogen budgets for, sardine Sardinops sagax in the southern Benguela upwelling system. PhD dissertation, University of Cape Town

* van der Lingen CD, Hutchings L, Field JG (2006) Comparative trophodynamics of anchovy Engraulis encrasicolus and sardine Sardinops sagax in the southern Benguela: Are species alternations between small pelagic fish trophodynamically mediated? Afr J Mar Sci 28:465-477

van der Lingen $C D$, Bertrand A, Bode A, Brodeur R and others (2009) Trophic dynamics. In: Checkley D, Alheit J, Oozeki Y, Roy C (eds) Climate change and small pelagic fish. Cambridge University Press, New York, NY, p 112-157

Venrick EL (1972) Small-scale distributions of oceanic diatoms. Fish Bull 70:363-372

*Watanabe Y, Saito H (1998) Feeding and growth of early juvenile Japanese sardines in the Pacific waters off central Japan. J Fish Biol 52:519-533

Zhou M, Huntley ME (1997) Population dynamics theory of plankton based on biomass spectra. Mar Ecol Prog Ser 159:61-73

Submitted: September 18, 2017; Accepted: March 7, 2018 Proofs received from author(s): June 12, 2018 